\title{
EVALUATION OF (SELF-)DEVELOPMENT OF INTERCULTURALITY EXPERIENCES IN INFORMAL LEARNING ENVIRONMENTS
}

\author{
Ieva Bilbokaitè-Skiauterienè \\ Vilnius University Siauliai Academy, Lithuania \\ Renata Bilbokaitė \\ Vilnius University Siauliai Academy, Lithuania
}

\begin{abstract}
Political, economic, social and cultural changes of the country influence the change of the educational content. Striving to develop dynamic modern Lithuanian's and person's modern nationality, the educational content should relate to "pupils' experiences and sociocultural needs. The article presents that the development of interculturality of pupils is one of the approaches when striving to understand cultural diversity of the present-day world. The results of previous research (Bilbokaite, 2017, 2016) have revealed the lack of programmes, clear guidelines for intercultural education in the context of the different learning environments. The article describes importance of informal education, that arises from the learner's involvement in activities that are not undertaken with a learning purpose in mind.

The research aim is to reveal pupil's (of the 10th-12th Forms) opinion about the (self)development of interculturality in informal learning environments. Quantitative research was used (sample of 727 Lithuanian comprehensive school pupils) to investigate practical application of development of interculturality in educational environment from pupil's perspective. The research results analysed employing content analysis reveal the importance of learning from the experience as a fundamental and natural means in different environments - home, social networks, school, city, streets. Safe personal environment creates the opportunity to be self, to learn about values, variety of cultures, tolerance, acceptance of others. Pupils' opinions concerning the lack of possibilities for development of interculturality in school (during formal education) are presented.
\end{abstract}

Keywords: (self-)development of interculturality, experiences, informal learning environments, Lithuania, pupils, content analysis.

\section{Introduction}

The crossing of both culture and globalisation process is dealt with in studies of many scientists who underline importance of a dialogue (Chumakov, 2013), the culture turning global (Cowen, 2004; Laszlo, 2012; Pieterse, 2003), changes in the lifestyles of society members and their values (Giddens, 2003; Klimova, 2011; Mozaffari, 2002; Tutchener, 2013; Huntington, Harrison, 2000), manifestation of diversity (Johnston \& Hiwasari 2012; Robertson, 1995). The 
rapid pace of technologies, changes in the cultural and social relationships are emphasised by contemporary researchers (Longhurst, 2007; Husted, 2003; Giddens, 2000) who highlight inevitable cultural changes caused by these processes as the reality of present-day social life, manifesting through interaction with other cultures, groups of individuals, while accepting new ideas, different experiences, forming values and beliefs.

Education-related legal acts of the European Union and the United Nations, strategic documents (Europe 2020: A Strategy for Smart, Sustainable and Inclusive Growth, UNESCO Universal Declaration on Cultural Diversity, 2001, the programme of the UN Decade of Education for Sustainable Development: 2005 - 2014, etc.) regulate the striving for the fostering of cultural diversity as a guarantee ensuring survival of the humankind, emphasising the fostering of culture as "the set of distinctive spiritual, material, intellectual and emotional features of society or a social group, and that it encompasses lifestyles, ways of living together, value systems, traditions and beliefs" (UNESCO Universal Declaration on Cultural Diversity, 2001).

The development of interculturality of pupils is one of the approaches when striving to understand cultural diversity of the present-day world, changing personal identity and values, to accept cultural changes, enhancing the principles of equality, acceptance of differentness as well as manifestation of respect and tolerance. Also, pupils' abilities of interaction and communication with members of their group and surrounding environment are being developed (Bhawuk \& Brislin, 2000).

Informal education, as well as the Non-formal and formal one, "prepares young people for the challenges and responsibilities that they will undertake in the adult life" (Lafraya, 2011). Today's education, whose goal is to educate an independent, active, creative, open to innovations and change personality, gives an opportunity to learn in various contexts and participate in processes of change. "The importance of assessing and recognizing the achievements of informal learning has, therefore, been increased" (Petnuchova, 2012) in this context. According to S. L. Tudor (2013)" informal learning is a very effective method of learning and probably the most common among adults". Analysis of scientific literature revealed complexity of successful informal learning that encourage development of a dialogue, intercultural relation based on critical thinking, while focusing special attention on interpersonal relationships, developing abilities to interpret cultural phenomena, promoting respect, tolerance, acceptance of the Other/ different.

Scientific relevance is indicated by the Lithuanian scholars who emphasises the lack of research studies dealing with tolerance, social exclusion, cultural 
change and practical design of intercultural learning (Bakonis et al., 2004; Dailidienè, Lukošiūnienè, 2003).

The research aim is to reveal pupil's (of the 10th-12th forms) opinion about the (self-)development of interculturality in informal learning environments.

The problem of the research. Striving to meet the challenges set by globalisation, while building the foundations of a modern state open to the contemporary world, the strategy of Lithuanian progress focuses on several directions: openness, dialogue-based commonality with the otherness, cultures are promoted through re-consideration of own national identity vs fostering national identity, traditions and heritage, remaining the tradition-based society. In compliance with the challenges set for education, orientation of the educational content towards awareness of intercultural meanings is promoted; this may be achieved through updating curricula open for creativity, searching and perfection, initiating teacher training, designing informational resources, teaching aids, applying up-to-date educational technologies. However, such preconditions require a broader evaluation which supposes the problem question - what informal learning environments do influence (self-) development of interculturality of pupils?

\section{Theoretical Basis of the Study}

With regard to expectations of the changing society, it is aimed to implement the changes in education oriented to the changes caused by the technologies of globalisation, economics, policy, accepting social-cultural factors. This stimulates the focusing on education based on inter-disciplinarity, integrity, values (de Leo, 2010; Osuna, 2013; Seyfried, 2014). The National Strategy of Education for 2013 - 2022 emphasises that education institutions aiming to implement their purpose, i. e. to assist pupils in becoming full-fledged members of democratic society, while adjusting to the changing culture, ground on the following value principles: "humanity, democracy and equal opportunities, civic spirit, implementation of freedom and ethics, tolerance and dialogue; national identity, continuity of the tradition and openness to cultural diversity". This way, traditional (ethnic, folk) culture as the fostering of historically established ethical concepts, cultural values taken from past generations, through which national identity is revealed, is being highlighted, meeting the needs of the changing society becoming more modern.

The process of globalisation makes impact on cultural changes (Ladhari et al., 2015) when in the context of interaction of nations foreign values are being integrated, the youth forget their culture, are not interested in customs and traditions, when old rituals are substituted by new ones being promoted by the mass culture of consumerism or economic market. Because of complexity of the 
constructs and applicability of the meanings rendered to them when constructing identities grounding on political, social and economic processes, the multidimensional perception of culture undergoing transformation is changing, when it is difficult to concretise the transformations of the values of society members, models of living and social activities, behaviour stereotypes, norms, ideals. On the ground of scientific insights of foreign scholars (Osovsky, 1997; Cucos, 2000; Delors, 2013; Chiriac \& Panciuc, 2014), it can be summarized that intercultural education in school aims at stimulating human rights by developing selfconfidence in class, striving to help the youth find themselves as members of both national and global community, this way forming the mentality and character of own country.

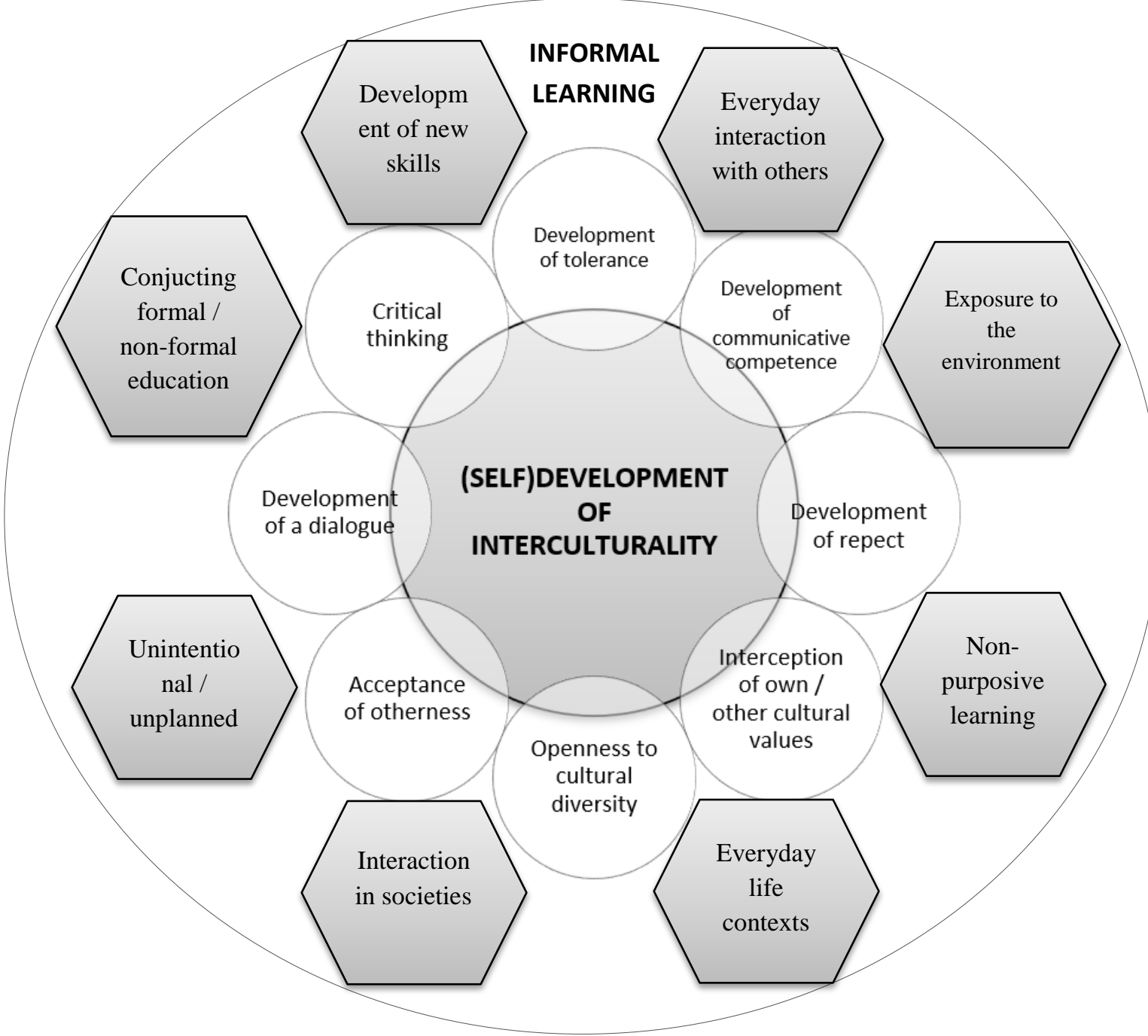

Figure1 Theoretical Model of Informal Learning Coherence to (Self)Development of

Interculturality (designed by the authors, according to Seyfried, 2014; Chiriac \& Panciuc, 2014; Tudor, 2013; Lafraya, 2011; Bilbokaitè, 2016; Jeffs \& Smith, 2005, etc.) 
In order to achieve aim of research it's important to understand and define theoretical conception of informal education and its interfaces with selfdevelopment of interculturality of pupils (Figure 1). As Farahani et al. (2014) classified "gaining the necessary skills in the changing global world shows that learning in the especial places of learning and in specific periods is not enough". That reveals the importance of informal learning - a process where learning from experience and various activities, that help people to learn new skills, takes place, wherever people have the need, motivation, and opportunity for learning.

The definition of informal learning is not fully supported, although "it is clearer than the idea of non-formal learning” (Tudor, 2013). It is difficult to make a clear distinction between informal and non-formal learning because it can maintain a close relationship with both. According to J. Petnuchova (2012), "informal learning is an element of non-formal learning".

According to McGivney (1999) "some informal learning takes place in formal educational environments (such as schools) while some formal learning takes place in an informal local setting (such as church or village halls). As Coombs \& Ahmed (1974) states informal education is "the lifelong process by which every individual acquires and accumulates knowledge, skills, attitudes and insights from daily experiences and exposure to the environment”. Lafraya (2011) and Chisholm (2005) ideas about formal, non-formal and informal education help to establish the characteristics of informal education: it takes place on an unintentional and unplanned basis in the individual's everyday interaction with others; from the learner's standpoint, this is non-purposive learning which takes place in everyday life contexts in the family, at school, during leisure and in the community.

McGivney (1999) states that informal learning can be "unplanned, incidental, unintentional and surplus" to any explicit aims. It is very important to outline that it occurs "through dialogue" and explains how such learning might be utilised for interaction with others. According to S. Lafraya (2011) informal education describes socialisation, it is "non-organised and incidental learning that goes on in daily life". Every day experience creates opportunities for learning, e. g. through reading a book, watching television, communicating on social networks. Pupils are also involved in learning with others - at school (lectures in institutions, visiting museums), at home (scientific or didactic games, manipulation of kits, experiments, reading sessions) and in the various social to which they belong (Jeffs \& Smith, 2005). C.Z. Dib (1988) emphasises the following activities that informal education comprises: "visits to museums, listening to radio, watching TV (on educational or scientific themes), reading texts on sciences, education, technology, participating in scientific contests, attending lectures and conferences". It should be noted that informal education does have outcomes, but these are "seldom recorded, virtually never certified and are 
typically neither immediately visible for the learner nor do they count in themselves for education, training, or employment purposes” (Chisholm, 2005).

\section{Research Methodology}

In 2019, quantitative research method - a online questionnaire-based survey of Lithuanian comprehensive school pupils (10th-12th forms) was used. The research involved 727 respondents (Table 1). The researchers designed the research instrument grounding on defined and specified diagnostic areas and characteristics of the research. The research instrument is the questionnaire with the following sections: the conception of interculturality, the activities held at school and stimulating interculturality, the shortage/ limitations of interculturality, reasons for the lack of interculturality, key aspects of interculturality, conditions for development of them at school. Aauthors are using the data that are obtained from open-end type questions in this study, aiming to investigate experiences in informal learning environments and what was their meaning in the process of development of interculturality.

Table 1 Sample Characteristics of Participants of the Research

\begin{tabular}{|c|c|c|c|c|c|c|c|}
\hline Gender & Percent & Age & Percent & Nationality & Percent & $\begin{array}{c}\text { Place of } \\
\text { residence }\end{array}$ & Percent \\
\hline Female & 56,8 & 15 years & 0,7 & Lithuanian & 93,9 & City & 49,0 \\
\hline Male & 43,2 & 16 years & 28,1 & Polish & 2,6 & Village & 51,0 \\
\hline & & 17 years & 32,0 & Russian & 1,5 & & \\
\hline & & 18 years & 31,9 & Belarusian & 0,4 & & \\
\hline & & 19 years & 7,3 & Ukrainian & 0,4 & & \\
\hline & & & & Other & 1,1 & & \\
\hline
\end{tabular}

Research ethics. Before conducting the research, the purpose of the research, the methodology and the conditions of publishing the results were explained to the respondents. Ethical principles of research were followed in the survey. The ethics of the research is based on a respectful attitude towards the participants.

The article presents data of the analysis of informal environments for (self)development of interculturality, supplementing theoretical insights. To carry out data analysis, the method of content analysis was employed. The content of the text has been analyzed consistently, by dividing the pending content into analytical segments, i. e. categories, subcategories. They are coded (e.g. [1] and similar) according to the order of questionnaire, submitted by research participants, in order to ensure their anonymity. In their answers, the pupils 
recorded their opinions and attitudes. The research results may be the ground for further broader investigations.

\section{Research Results: Analysis of Informal Learning Environments in Intercultural Education}

Learning environments are understood as the areas of people's lives and activities that have an educational value, enabling an individual's personal development, which is realized through learning efforts (Jucevičienè, 2001). The research participants singled out home, social network, and school environments (Figure 2) in which, if they recognize intercultural situations, they learn from. The analysis of the research data revealed that students spend most of their time in the HOME ENVIRONMENT. In it, by interacting with diverse people and experiencing various situations, the latter gain the most experience, which develops interculturality. The possibility of being yourself is emphasized, because "only there you can relax and not worry about what those around you will say, you can accept others, their differences. At home, you behave as you wish" $[1,678]$. This view is echoed that "if not family, I would hardly be able to be myself and accept others, no matter how different they are" [649]. This is encouraged by communication with family and friends. According to the participants of the study, "you can be yourself at home and nobody will bully or humiliate you" [671], so they feel safe in this environment.

Learning from parents becomes an important factor when the principles of values and equality, empathy, and respect for otherness are developed. This is "the best place to learn from family members" [99]. First of all, it is noted that ,in the home environment $<\ldots$.. $>$ family cultivates the values of each person" [305]. At the same time, it is taught to accept others as they are [123, 483], to tolerate everyone [545], to "behave politely, treat others with respect" [509]. The following example illustrates this: „my parents have a friend whose son has Down syndrome. My parents taught me tolerance from an early age, not to make fun of, to play together” [494]. Parents teach that ,all are equal” [708]. It is also emphasized "when cultivating interculturalism you are developing yourself, your perception, your understanding in respect of others" [516], because parents develop personality "by helping them to get acquainted with everything" [666] and by passing on their experiences. The understanding of other countries is emphasised [7, 711, 74], when the opportunities are provided at home to "take an interest in different nations and countries" [640], the discussions take place about "the cultures of other countries" [243]. As the pupils' state, "there are questions I ask every person close to me. When I get answers, I get to know other nations, their culture" [353]. It is emphasized that "tolerance for foreigners is taught at home” [7, 64], "respect for others is introduced" [28]. At home it is spoken why 
"we have to accept people as they are, regardless the nationality and so on" [505], "respect other people, people of other nations, not to make fun of them" [209], "respect everybody" [349], "behave ourselves" [660].

Home is a personal environment where students spend most of their time and feel safe, "do not feel any pressure, communicate easily, freely" [665]. At home children may "think everything over in a calm way" [111, 515], "focus on and concentrate" [337]. By watching movies, listening to foreign music [125], surfing the Internet [275], pupils learn to "not condemn others and understand them" [665]. An example is given where "the perception of interculturalism was most introduced by $<\ldots>$ an aunt, an experienced traveller. I especially admire her stories about different cultures, customs, and tolerance to others. It encourages me to break down stereotypes, barriers and integrate into the wider world" [217].

The importance of communication with foreigners is emphasized, when at home there are excellent conditions for communicating with them and "it encouraged the acceptance of people of other nations" [681].

The following example of such communication is provided when "I had to help the child at home, who came to Lithuania from abroad, communicate with other children" [261]. It is noted that communication is taking place with family members living abroad. Also, with friends they communicate openly with [565, 566]. Interculturalism is developed at home "via the Internet" [67, 154, 587], "equality" is learned [585] namely in this space, "one can find material about everything" [687], "read many articles and do not see bullying" [633]. One can get to know other nations by watching TV [696, 333, 285].

SOCIAL NETWORKING / VIRTUAL ENVIRONMENT. On the Internet and social networks pupils are given the opportunity to be themselves, to communicate with foreigners, various people, to develop tolerance, respect, to learn from situations, to accept others, to get to know different cultures. In the public online space, information is easily accessible [201, 191] both on various social networks and on news portals, computer games. The virtual environment "connects people of different cultures" [595], "it is possible to learn more and more about everything, perhaps even learn first-hand" [319], to get acquainted with various opinions [696], "to learn a lot of valuable information" [635, 478, 348]. It is emphasized that pupils feel safe namely in this environment and, on the contrary, at school they are afraid to express their views due to possible criticism and bullying ("it is difficult at school because it is scary to be criticized, it is scary you will be bullied" [562]). This choice of communication method is also influenced by the fact that pupils have limited opportunities to travel and communicate with various personalities. Pupils learn and receive information from "videos, photos, virtual museums" [511], “comments, specific situations" [692]. 
The opinion is that "when it comes to the Internet, social networks - I see, read and hear a lot here. I tend to notice that the Lithuanian audience is becoming more tolerant, understanding the representatives of another race or nationality. Nevertheless, the youth of the Lithuanian province still use uncensored vocabulary, brutality and insult others. There are now more and more social actions for equality, peaceful cooperation between countries around the world and I am pleased to see that. It's nice when we become cosmopolitan, but the current political and geographical situation is forcing some nations to look at it from a different angle. After various terrorist attacks, almost all Muslims are being condemned. I feel sorry for innocent women, children and men who sincerely believe in Allah and want peace and quiet in the world. This is hampered by the stereotype about all Muslims that they are all terrorists, as many claim" [572].

The most pronounced category is Communication with foreigners, emphasizing the possibility to communicate "live, easily" with "citizens of a different way of life or thinking" [697] and get to know them [27, 486, 342 56], "to share their thoughts, ideas and life experiences" [366]. This experience helps pupils "in communication with new people and making new friends. By communicating with foreigners our knowledge enriches, we learn a lot more about other people, and maybe even about ourselves" [57]. Communication in the public space allows us to assume that foreigners "are not valued or insulted in any way. Lithuanians avoid them and are sceptical" [644]. It is noted that "there is no such possibility at school" [554]. An example is given when "I had to talk to an American using Skype while playing one online game. He told me in detail about his hobbies, housework, his future plans, the cultural buildings and places of attraction in his city. It was a great experience not only to learn about the hobbies of a foreigner, but also to speak in a more acceptable language - English to him [573]. An open mutual communication reveals that all people are equal, similar, regardless of their beliefs, religion, and nationality [238].

Emphasis is also placed on communication with a variety of people who express different views [450, 290, 249, 612, 607, 479]. This allows students to communicate with more freedom [527], to understand and get to know people, their culture, which is perceived as a "continuous path of human development" [194]. The category of acceptance of others is distinguished, when by communicating on social networks and analysing material on the Internet, pupils can "be themselves and accept others, no matter how different they are" [56]. Human differences, their otherness are taken for granted, recognizing that diversity is an integral part of today's world and "irrelevant to race, gender, or social status" [234]. Pupils are "just happy to communicate, the opinion of others is interesting. In the virtual space everyone in different corners of the world can 
share their experiences, impressions" [235], "communicate with each other politely, tolerate others" [523].

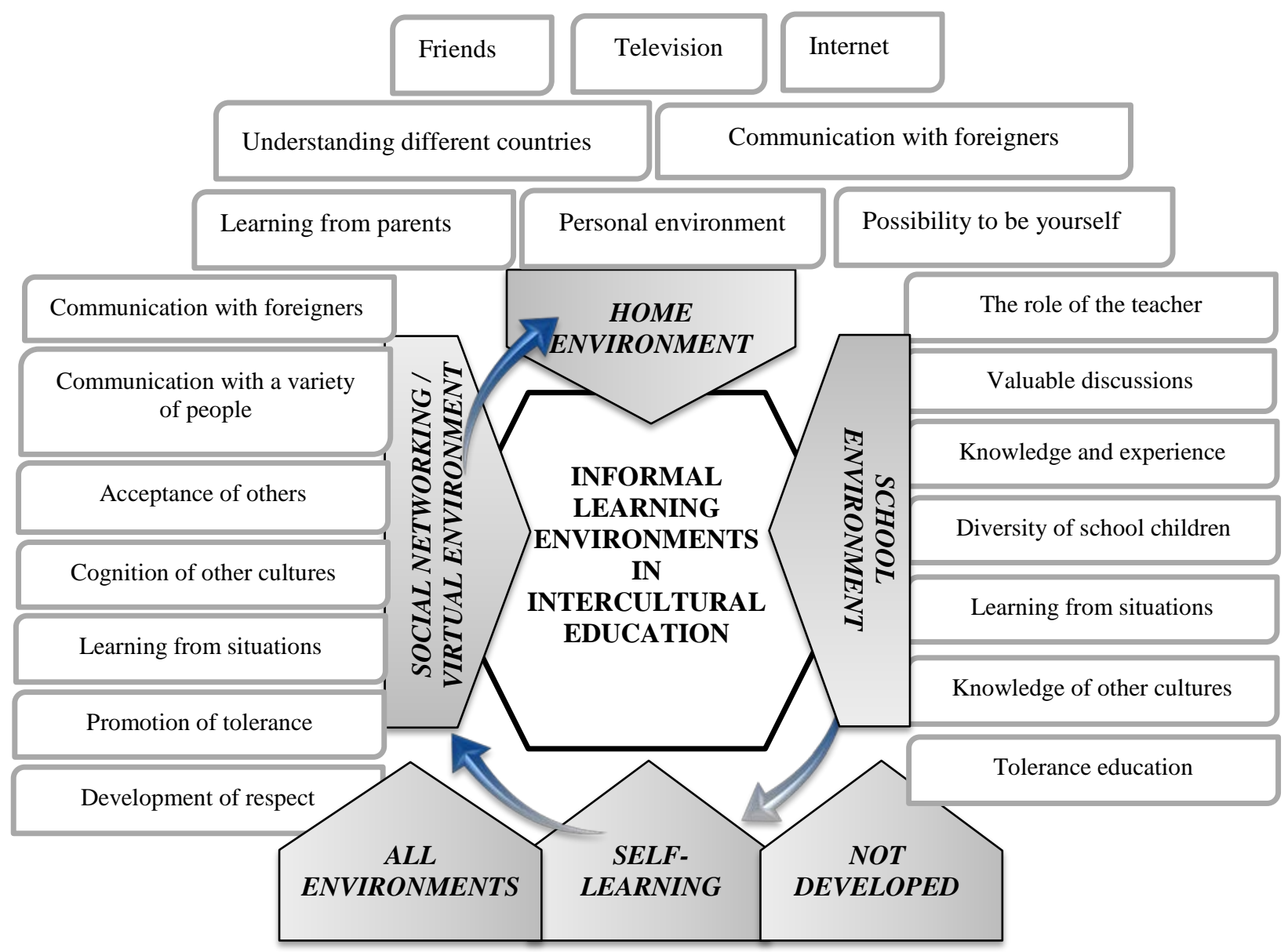

Figure 2 Schematization of Informal Learning Environments in Intercultural Education (designed by the authors of the research)

Emphasis is placed on cognition of other cultures, when "such communication teaches to know other countries, their cultures, languages” [225], "traditions and customs" [501], "religions, cultures, holidays" [518]. At the same time experiences are shared, "a common conversation field is created" [48], when the access to moments in people' s lives such as following interesting people on Instagram, Facebook, Youtube, etc. is given" 141]. Communication with emigrants and analysis of their experience, how "their attitude has changed, how they identify themselves, what group they belong to, because they have already become "the Lithuanians of the world" takes place [221]. Communication on social networks gives experience, "you see, learn something new, and thus you develop, educate yourself" [460]. There is also a contradiction, stating that "social networks are also good for this purpose, but nowhere else will they learn interculturalism as in real life, by actually communicating, seeing and living” 
[460]. Pupils note the importance of communication (language) skills, such as "I listen to K-POP Korean pop, I like it because of its music, and I find the lyrics translated to understand what they are singing about" [236]. It is said that there is an interest in "Indian culture, their customs, specifically their painting on the body, which has many meanings in their culture" [358].

It is noted that learning from situations that "help to choose" is very important [232], because "many different and diverse people are involved" [95]. Learning from situations is assessed as the "best lessons" [232]. Learning does not only take place on social networks, where a lot of time is wasted, but also "in the street" [95]. Namely, social networks "provide many good examples and are best explained, $<\ldots>$ there are all the conditions for communication, people and their experiences" [507]. It is noted that "by interacting online where there is a wealth of information about other cultures, I become more familiar with other people's ways of life and become more tolerant. In today's world, where people of different religions, cultures, nations mix, it is difficult to be intolerant towards other cultures" [253].

It is emphasized that "there are many different images and recordings in the social space that promote tolerance" [725], in which "you get to know too many different personalities, which helps you to unfold, become more tolerant” [354]. It is emphasized that there is also bullying in social networks, intolerance of foreigners, people of other faiths or races, but pupils "feel responsible and understand that everyone is different and therefore accept others tolerantly" [564]. An example how to develop tolerance is given: "I like Facebook the most because you can see different types of people there. But everyone there tries to be tolerant, friendly. There was a situation when everyone in Facebook friends started making fun of one girl and the others defended her. Since then, I have realized that it is always better to be a tolerant person than to insult another" [524].

Emphasis is also placed on the development of respect, which states that when communicating on social networks people "should respect the other" [660], promote various agitation for the rights of others [367]. An example is given where "people on a social network <...> gather from all over the world to create their blogs. $<\ldots>$ A lot is written about feminism, sexism, the situation of refugees from Syria, Belarus, <...> about social problems. From there, I formed my attitude that one cannot judge others and must respect everyone, no matter how different they may be" [75].

Self-presence becomes important when it is stated that on social networks, people's behavior encourages, "stimulates being yourself, etc."[203], as learning develops "from what you see or hear" [254]. It is noted that on the Internet "communication is open, free" [510], "there is no pressure" [665], one feels "having more freedom to speak, to express their opinion" [258]. It is this space 
that teaches to accept others, no matter how different they are, "learns not to condemn and to understand others" [665].

SCHOOL ENVIRONMENT develops interculturality through situations, communication with various children, by promoting knowledge of other cultures, development of tolerance, respect for others, self-development as a personality, cooperation, participation in project activities, exchange programs, clubs. The role of the teacher in conveying information to students is emphasized, when the analysis of various topics, discussions and sharing of experience in the classroom promotes intercultural knowledge. Pupils recognize examples of intercultural education differently. It is noted that "I learn interculturality every day [658]", but the opinion is expressed in opposition - it is "occasionally" [184] "mentioned" [109] at school. In the school environment pupils have the opportunity to communicate ("we talk about it all there" [186]), "everyone teaches something in it" [525], and during the lessons "it is spoken about interculturalism" [345] and this gives opportunity to "learn a lot" [478].

The role of the teacher in "helping to understand" [708], developing interculturalism is emphasized. The experience and knowledge conveyed by teachers become an example for students ("teachers help to take note of various examples given of how others standing out are protected, for example, bullying towards Romanians" [688], "I see a good example" [325]). Teachers discuss various topics with their pupils. The school becomes a space where students "meet all kinds of different people and can discuss interculturalism" [124, 339], "its features, tolerance, cooperation" [697], gain knowledge and experience when "learn better qualities while being with others [2]. "There are people who teach in this environment and who share their experiences” [626]. Pupils are provided with access to the necessary information [635], which stimulates their interest.

Emphasis is placed on learning from the diversity of school children when interacting with children from "different families, orphanages, etc." [248], "other countries" [490], "different nationalities and religions" [260], "with different personal characteristics" [5]. By communicating, spending free time or participating in extracurricular activities, pupils learn together "the customs and differences of an innovative culture, different stories" [260]. Also, communication with people of "different attitudes" and "different perspectives" [479, 482] requires the ability to "adapt, no matter how difficult it is" [547]. Pupils achieve this by “respecting everyone, even if they don't really want to, or do not really like them" [248], by trying to "understand their classmates and teachers, understand their psychology and learn to communicate with them, accept them as they are, without resorting to conflict, etc." [97]. Various knowledge emerges during discussions with like-minded people or, conversely, among those "with differing opinions". An important aspect is that at school students feel comfortable when interacting with both students and teachers, and this gives them 
the opportunity to "accept them as they are" [448]. Communication with "students of other nationalities, ages, different schools, attitudes to life, beliefs, height and weight," [360, 342] promotes respect of pupils, noting the relevance of accepting differences ("we must respect them, they are not guilty that they come from poor countries or smaller than our cultures, their skin color differs, because we are all human, the same" [490]).

Pupils emphasize the importance of learning from situations, when "cultures are introduced through various situations, respect for the representatives of the other countries is taught" [215], "various situations with tolerance happen” [139]. Pupils' experiences are influenced by the time they spend at school [578, 340] and the environment in which they have access to all the necessary information from the people around them ("there are questions I ask every person close to me. When I get answers, I get to know other nations, their culture” [353]).

The category of knowledge of other cultures is especially distinguished, the name of which indicates that in the school environment pupils get acquainted with various cultures [6, 7], learn about other people during Lithuanian lessons [252]. In this environment, pupils mainly talk about "cultures of other countries" [243, 362], "their customs and rights" [549], get acquainted with traditions of other countries [543], religions [335], intercultural non-verbal differences ("I learned that Bulgarians shake their head negatively, which means "yes" [608]), learn to accept “one's own culture and other cultures" [678]. Teachers pass on their knowledge to pupils ("there are many good teachers at school who teach about cultures and beyond" [112], "teachers talk about different cultures" [542]). This information develops respect and tolerance for the differences of nations / individuals ("I realized that they need to be respected, tolerated" [361]). Emphasis is placed on the category of tolerance education, when students must follow appropriate rules in the school environment, for example, "be tolerant towards each person" [660], "tolerate others because of their appearance and behaviour" [660].

It is noted that interculturalism is fostered in ALL ENVIRONMENTS, whether "on the street, at home, at school, on social networks" [650], "at school, in the city, in extracurricular activities, by watching movies, reading books, attending events, concerts, exhibitions, etc. wherever people are present” [698]. Pupils note the need to accept people as they are, no matter what the situation is. The most important thing is communication, which allows you to get to know people. It is noted that "teachers must teach interculturalism at school" [498].

Emphasis is placed on children's SELF-LEARNING, where environments such as the Internet [75] or homes, youth organizations, encourage them to learn and provide new ideas. Mostly learning from life situations takes place. It is stated that "no one encouraged it during the lessons, I have my own head" [64], "I have my own beliefs" [274], "I encouraged myself” [175]. It is stated that "I have learned everything online and by interacting with people from different cultures / 
subcultures / social groups” [75], "everyone has to assess interculturality according to their own perception, because values will not be instilled in a person if he does not want to" [356].

Some students expressed their view that interculturalism is NOT DEVELOPED in a general education schools, emphasizing that "the school does not try to promote it" [22], "such subjects are not addressed" [141], "the school does not pay much attention to this issue, so it is difficult to comment”. [200], "there is no motivation" [144]. It is noted that "the school does not pay attention to interculturalism and each personality develops it independently" [146], "in no lesson interculturality is promoted, I just understood it myself" [201]. Various preventive events, such as Bullying Prevention Week, are seen as an insufficient period to "learn something about tolerance or interculturalism" [75]. It is emphasized that "no intercultural education is observed in any of the lessons" $[110,555,343,547,548]$. Here are some examples to illustrate the latter opinion of students:

"Well, first of all, it's a rare occasion for you to hear about interculturalism, tolerance at school. We talk mainly about the development of Lithuania, what Lithuanians are like, and foreigners are condemned. Because of this kind of Soviet teacher thinking, I think it's time at school to change old teachers into recently graduated, liberal-minded youth. I realized that our school still has room for improvement, and we learn about tolerance and interculturalism ourselves" [665]; "Indeed, it is difficult to name a lesson that is about tolerance towards other nations. Yes, other cultures are mentioned during English lessons, but they are only introduced superficially. Mostly communication with foreigners develops the sense of respect. Unfortunately, I have few such opportunities in my environment" [27]; "The school does not have much influence in terms of intercultural education. History lessons provide some information about the history and culture of other countries, but that's certainly not enough. Tolerance for someone else is innate, natural, I started to be interested in interculturalism on my own. Sadly, the people around are often full of prejudices and stereotypes, which is detrimental not only to other cultures but to all people. It is unacceptable to me that the school seems to divide people into certain categories, "boxes", encourages people not to open up, but only to close even more" [194] "In lessons that take place in the Lithuanian language, I am set against these things because education in Lithuania is "rotten" [233].

The lack of lessons is emphasized ("unfortunately, there are not many such lessons at our school" [26]). It is noted that there is a lack of opportunities to communicate with foreigners at school, which would "develop a sense of respect" [27]. It is stated that "most of the time there is only talk at school and no action. I believe that everyone, first of all, forms their interculturality from the living environment" [142]. Pupils do not have experience in interculturalism 
education [348, 392], by emphasizing that "I did not encounter that and did not consider that" [656, 349, 114].

\section{Conclusions}

The essential environments for self-development of interculturality are the following: home, social networks, school, where situations of interculturality are recognised, learnt from. A possibility to be self, the learning from parents, when value principles, comprehension, principles of equality, respect to differentness, opportunity to get acquainted with other cultures, self-development of tolerance, communication with foreign-born people, acceptance of others/ the different are being developed, are important. Safe personal environment becomes highly important. Self-development of interculturality is both recognised in all environments, i. e. on the street, at home, in school, social networks, city, while watching films, reading books, taking part in events, concerts, exhibitions etc., and the lack of development of interculturality in schools is emphasized when pupils lack motivation and experience.

The research results revealed that everyday learning from the environment takes very important part in the process of pupils (self-)development of interculturality. This reveals the need for further research, investigating informal education characteristics and its adaptation into today's education. The authors discover the need of non-formal / informal programmes which would help to enhance the principles of volunteering, cognition of the Other, integration into the cultural life of a city / country, by enhancing communication among community members, also by developing pupils'self-expression and creativity, active involvement in cultural, artistic, cognitive, scientific activities.

According to the results of the research pupils are developing interculturality not only at school environment, but also at home, in social networks and other environments, it is necessary to ensure effective collaboration between pedagogues and parents. It would allow to insure safe personal environment of pupils, to supplement intercultural situations occurring in school with those of the home environment or created by virtual environment, e. g. an opportunity to be oneself, to get acquainted with other cultures, communication with various people/ foreign-born people, assurance of equal opportunities. This can be implemented through participation in various activities such as projects, also involving both pupils and their parents, creating modern environments at school enabling learning from situations, providing experiences and motivation, new ideas to pupils; developing pedagogues'qualification, level of digital literacy, intercultural competences, stimulating design and implementation of modern educational scenarios in educational practice, by individualising the educational content, changing pupils'understanding of self-assessment, learning approaches. 
Bilbokaité-Skiauterienè \& Bilbokaitè, 2021. Evaluation of (Self-)Development of Interculturality Experiences in Informal Learning Environments

\section{References}

Bakonis, E. (2004). Lietuva pasaulyje. Kaunas: Šviesa.

Bhawuk, S., \& Brislin, R. W. (2000). Cross cultural training: A Review. Applied Psichology: An international Review, Vol. 9, p. 162.

Bilbokaite, I. (2016). Expression of Interculturality in Educational Practice from Pupils' Perspective. Proceedings of INTED2016 Conference, 4911-4917.

Bilbokaitè, I. (2017). Transformations of traditional Lithuanian culture influenced by interculturality: a case of Lithuanian 10th - 12th forms pupils' opinion. EDULEARN17: 9th international conference on education and new learning technologies: conference proceedings, 5300-5305.

Chiriac, A., \& Panciuc, L. (2014). Intercultural Education - Objectives, Values and Perspectives. New Perspectives in Science Education, Edition 4. Retrieved from: http://conference.pixel-online.net/NPSE/files/npse/ed0004/FP/1426-NTST861-FPNPSE4.pdf.

Chisholm, L. (2005). Bridges for Recognition Cheat Sheet. Proceedings of the SALTO Bridges for Recognition: Promoting Recognition of Youth Work across Europe. Leuven-Louvain.

Chumakov, A. N. (2013). Culture in the Global World: Between Dialogue and Conflict. In Grinin, Ilyin, \& Koratayev (Eds.), Globalistics and Globalization Studies, 291 - 299.

Coombs, P. H. \& Ahmed, M. (1974). Attacking Rural Poverty: How non-formal education can help. Baltimore: John Hopkins University Press.

Cowen, T. (2004). Creative Destruction: How Globalization Is Changing the World's Culture. Princeton: Princeton University Press.

Cucos, C. (2000). Educaţia. Dimensiuni culturale şi interculturale. Iaşi: Editura Polirom. In Dă nescu, E. (2015). Intercultural Education from the Perspective of Training Didactic Competences. Procedia - Social and Behavioral Sciences, Vol. 180, 537 - 542.

Dailidienè, V., \& Lukošiūnienè, V. (2003). Švietimas ir socialinè atskirtis. Suaugusiuju švietimo savaitès patirtis. Vilnius: Mintis.

de Leo, J. (2010). Education for Intercultural Understanding. Thailand: UNESCO Bangkok.

Delors, J. (2013). The treasure within: Learning to know, learning to do, learning to live together and learning to be. What is the value of that treasure 15 years after its publication? International Review of Education, Vol. 59, 319 - 330.

Dib, C. Z. (1988). Formal, Non-formal and Informal Education: Concepts/Applicability. Cooperative Networks in Physics Education - Conference Proceedings, Vol. 173, 300315.

Europe 2020. (2001). A Strategy for Smart, Sustainable and Inclusive Growth, UNESCO Universal Declaration on Cultural Diversity. Retrieved from: https://ec.europa.eu/eu2020/pdf/COMPLET\%20EN\%20BARROSO\%20\%20\%20007\% 20-\%20Europe\%202020\%20-\%20EN\%20version.pdf

Farahani, M. F., Mirzamohamadi, M., H., Noroozi, N. (2014). The Study on Features of Informal Education in Postmodernism. Procedia - Social and Behavioral Sciences, Vol. 136, 559-563.

Giddens, A. (2003) Runaway World: How Globalization is Reshaping Our Lives. New York: Routledge.

Huntington, S. P., \& Harrison, L. E. (2000). Culture Matters: How Values Shape Human Progress. Basic Books, New York. 
SOCIETY. INTEGRATION. EDUCATION

Proceedings of the International Scientific Conference. Volume VI, May $28^{\text {th }}-29^{\text {th }}$, 2021. 28-44

Husted, N. (2003). Globalization and cultural change in international business research. Journal of International Management, Vol. 9, 427-433.

Jeffs, T. \& Smith, M. K. (2005). Informal Education: Conversation, Democracy and Learning. Nottingham: Educational Heretics Press.

Johnston, B. R. L., \& Hiwasari, I. J. K. (2012). Water, Cultural Diversity, and Global Environmental Change: Emerging Trends, Sustainable Futures? New York: Springer.

Jucevičienè, P. (2006). Teaching in higher education: teacher as learning. Social Sciences, Vol. 3(53), 72-79.

Klimova, L. V. (2011). The relationship between globalization of society and transformation of personality values. Proceedings of the II International Scientific Congress "Global

Studies-2011: Ways to achieve strategic stability and the problem of global governance" (Moscow, May 18-22). Moscow: maks-Press, Vol. 2, p. 57-58.

Ladhari, R., Souiden, N., \& Choi, Y.-H. (2015). Culture change and globalization: The unresolved debate between cross-national and cross-cultural classifications. Australasian Marketing Journal, Vol. 23, 235-245.

Lafraya, S. (2011). Intercultural Learning in Non-formal Education: Theoretical Frameworks and Starting Points. Paris: Council of Europe Publishing.

Laszlo, E. (2012). Culture and the Sustainability of the Global System. Journal of Globalization Studies, Vol. 3(2), p. 3-9.

Longhurst, B. (2007). Cultural Change and Ordinary Life. Berkshire: Open University Press, Mc-Graw-Hill Education.

McGivney, V. (1999). Informal Learning in the Community: a Trigger for Change and Development. Leicester: NIACE.

Mozaffari, M. (2002). Globalization and Civilizations. New York: Routledge.

Osovsky, E. G. (1997). Pedagogical science in the Russian Abroad: Origins and landmarks. Pedagogika, Vol. 4, 88-94.

Osuna, C. (2013). Unexpected Consequences of Intercultural Education Policies in Bolivia. Anthropology in Action, Vol. 20(3), 4-10.

Petnuchova, J. (2012). Non-formal and Informal Education: Where Does It Go in the Slovak Republic? US-China Education Review, Vol. 6, 614-625.

Pieterse, J. N. (2003). Globalization and Culture: Global Melange. Lanham: Roman and Littlefield.

Robertson, R. (1995). Globalization: Time-Space and Homogenity-Heterogenity. Global Modernities. Featherstone: Robertson, 25-44.

Seyfried, C. (2014). Trust-Based Learning and Its Importance. Intercultural Education, Vol. 16(3), 1-6. Retrieved from: http://docs.lib.purdue.edu/clcweb/vol16/iss3/.

The National Strategy of Education for 2013-2022. (2013). Retrieved from: https://e-seimas.lrs.lt/portal/legalAct/lt/TAD/TAIS.463390.

Tutchener, D. (2013). Collective Identity and Heritage: Ebb and Flow at National and Global Levels. Journal of Globalization Studies, Vol. 4(2), 96-103.

UNESCO. (2005). The programme of the UN Decade of Education for Sustainable Development: 2005-2014. Retrieved from: https://unesdoc.unesco.org/ark:/48223/ pf0000141629_eng 